\title{
Nitrogen, science, and environmental change: the politics of the Green Revolution in Chile and the global nitrogen challenge
}

\author{
William San Martín ${ }^{1}$ \\ University of California, Davis, USA
}

\begin{abstract}
The widespread use of nitrogen $(\mathrm{N})$ fertilizers during the second half of the $20^{\text {th }}$ century radically transformed agricultural production and ecosystems on a global scale. Although the " $\mathrm{N}$ challenge" or the "N problem" has had limited public attention compared to biodiversity loss and climate change, scientists consider $\mathrm{N}$ pollution a leading ecological concern for the $21^{\text {st }}$ century. Accordingly, a major challenge for scientists and policymakers around the world today is how to meet food production demands while also protecting the environment. Using Chile as a case study-one of the highest consumers of $\mathrm{N}$ fertilizer per hectare in the Americas-this article examines the transnational politics of production and destruction in this process of agricultural modernization. In the Cold War context, a transnational network of scientists, agencies, and authorities created an institutional framework for the transference of knowledge and technology in Chile during the 1960s. Paradoxically, as local and global reliance on N fertilizers increased, scientists were able to generate a narrative about the negative environmental effects of intensive $\mathrm{N}$ use and highlight the ecological limits of the Green Revolution. After 1973, however, this knowledge network suffered as a result of the Chilean government's anti-communist crackdown and adoption of market-based agricultural policies. Understanding this history of how politics shaped $\mathrm{N}$ consumption, science, and policy is critical to current efforts to create new of agricultural production on a regional and global scale.
\end{abstract}

Keywords: nitrogen, fertilizers, the Green Revolution, Cold War, Chile, science, environment, policy, Global Nitrogen Challenge, agriculture, United States

\section{Résumé}

L'utilisation généralisée des engrais azotés $(\mathrm{N})$ durant la seconde moitié du XXe siècle a transformé radicalement la production agricole et les écosystèmes à l'échelle mondiale. Les scientifiques considèrent la pollution $\mathrm{N}$ comme une préoccupation écologique majeure pour le 21ème siècle. Mais le "défi $\mathrm{N}$ " ou le "problème N" a eu une attention limitée du public par rapport à la perte de biodiversité et au changement climatique,. En conséquence, un défi majeur pour les scientifiques et les décideurs du monde entier aujourd'hui est de répondre aux demandes de production alimentaire tout en protégeant l'environnement. En utilisant le Chili comme étude de cas - l'un des plus grands consommateurs d'engrais $\mathrm{N}$ par hectare dans les Amériques - cet article examine la politique transnationale de production et de destruction dans ce processus de modernisation agricole. Dans le contexte de la Guerre froide, un réseau transnational de scientifiques, d'agences et de autorités a créé un cadre institutionnel pour le transfert de connaissances et de technologie au Chili au cours des années 1960. Paradoxalement, à mesure que la dépendance locale et mondiale sur les engrais $\mathrm{N}$ augmentait, les scientifiques pouvaient générer un récit sur les effets environnementaux négatifs de l'utilisation intensive de $\mathrm{N}$ et mettre en évidence les limites écologiques de la «Révolution verte». Après 1973,

\footnotetext{
${ }^{1}$ William San Martin, Ph.D. Candidate, History Department, University of California, Davis, Davis, CA, 95616, USA. Email: wsanmartin "at" ucdavis.edu. Visiting Scholar, Program in Science, Technology, and Society and History Section, Massachusetts Institute of Technology, 77 Massachusetts Ave, Cambridge, MA 02139. Email: wsanmart "at" mit.edu. The author wishes to thank the editors of this Special Section, Javiera Barandiaran and Casey Walsh for their insights as well as Lovell Jarvis, Deborah Fitzgerald, Harriet Ritvo, Tanalis Padilla, Michael Wolff, Sebastian Castro, Barbara Silva, Jessica Fowler, and Tracy Quan for their feedback on earlier stages of this research and drafts of this article. This article is part of the author's dissertation entitled Nitrogen revolutions: science, policy, and the challenge of sustainability in Cold War Chile and its aftermath. This project was partially funded by the Fulbright Commission, Chile's National Commission for Scientific and Technological Research (CONICYT), and the Division of Social Sciences, Graduate Studies, and History Department of the University of California, Davis. This is the fourth article in Javiera Barandiarán and Casey Walsh (eds.) 2017. "Production/destruction in Latin America", Special Section of the Journal of Political Ecology 24: 716-800.
} 
cependant, ce réseau de connaissances a souffert de la répression anticommuniste du gouvernement chilien et de l'adoption de politiques agricoles basées sur le marché. La compréhension de cette histoire de la façon dont la politique est axée sur la consommation, la science et la politique de $\mathrm{N}$ est essentielle - pour les efforts actuels visant à créer une nouvelle production agricole à l'échelle régionale et mondiale.

Mots-clés: azote, engrais, révolution verte, guerre froide, chili, science, environnement, politique, Global Nitrogen Challenge, agriculture, États-Unis

\section{Resumen}

El extendido uso de fertilizantes de nitrógeno $(\mathrm{N})$ durante la segunda mitad del siglo XX, transformó radicalmente de manera global la producción de la agricultura y los ecosistemas. A pesar de que el "Reto N" o el "Problema N" ha tenido una atención limitada en comparación con temas como la pérdida de la biodiversidad y el cambio climático, científicos consideran que contaminación $\mathrm{N}$, es una preocupación primordial para el siglo XXI. Por tanto, satisfacer las demandas de producción de alimentos a la par de la protección del ambiente, es actualmente un reto para científicos y quienes hacen políticas públicas alrededor del mundo. A partir del caso de Chile -uno de los mayores consumidores de fertilizante $\mathrm{N}$ por hectárea en América- este artículo examina las políticas transnacionales de producción y destrucción en el proceso de modernización de la agricultura. En el contexto de la Guerra Fría, una red transnacional de científicos, agencias y autoridades, crearon en la década de 1960 en Chile, un marco institucional para la transferencia de conocimiento y tecnología. Paradójicamente, a medida que la dependencia a los fertilizantes $\mathrm{N}$ aumento local y globalmente, científicos fueron capaces de generar una narrativa acerca del intensivo uso de $\mathrm{N}$ y sus efectos negativos en el medio ambiente, y así marcar los límites ecológicos de la Revolución Verde. Sin embargo, después de 1973, esta red de conocimiento se vio afectada como resultado de las medidas anticomunistas y la adopción de políticas de agricultura basadas en el mercado, por parte del gobierno Chileno. Para los actuales esfuerzos de crear una nueva producción agrícola a escalas regional y global, resulta crítico el tener un entendimiento de la historia de cómo las políticas dieron forma al consumo, la ciencia y las políticas de nitrógeno.

Palabras clave: nitrógeno, fertilizantes, Revolución Verde, Guerra Fría, Chile, ciencia, medio ambiente, políticas, reto global del nitrógeno, agricultura, Estados Unidos.

\section{Introduction}

Nitrogen (N) fertilizers were a critical component of the programs that transformed agricultural practices and production around the world through the so-called Green Revolution. The dramatic increase in the consumption and use of $\mathrm{N}$ fertilizers during the second half of the $20^{\text {th }}$ century was crucial to feeding and clothing the growing world population. However, change in land use and agrochemical inputs including $\mathrm{N}$ fertilizers transformed not only soil management and agricultural practices, but also natural biochemical cycles on Earth (Boyer 2002; Galloway and Cowling 2002; Jenkinson 2001; Keeney and Hatfield 2008; Mosier et al. 2004; Smil 1999, 2004; Vitousek et al. 1997, 2002). ${ }^{2}$

The dialectic of production and destruction has been at the center of this process of agricultural modernization. Authorities, agrochemical corporations, and large agro-industries have stressed a narrative of success for decades (e.g. Rohter 2007). They have emphasized fertilizer access and other improvements as the ultimate solution to combat hunger and to bring economic progress to the undeveloped world. However, largely absent from these accounts is recognition of how political, ideological, and economic factors shaped these processes and hindered the incorporation of specialized knowledge about the (mostly negative) ecological effects of intensive $\mathrm{N}$ fertilization into public debates and policies. Despite a lack of public awareness, scientists consider $\mathrm{N}$ loss into the environment a leading socio-ecological problem in the $21^{\text {st }}$ century. Analyzing the history of $\mathrm{N}$ and agricultural change as a production/destruction dialectic highlights

\footnotetext{
${ }^{2}$ Other scholars have stressed the role of organic and mineral fertilizers (Peruvian Guano and Chilean Nitrates) in transforming soil management and altering the global nitrogen cycle during the 19th century (Cushman 2013; Melillo 2012). However, $N$ content in Guano and Nitrates are between $15 \%$ and $20 \%$, while in most used synthetic fertilizers (Ammonium Nitrate and Urea) N content ranges between 35\% and 46\%, respectively. Smil (2001: 40, 46, 135).
} 
important links between politics, food production, and environmental change that are critical to developing sustainable agricultural practices and policies.

For decades, scholars from different disciplines have studied the role of politics and economics in technological change in global agricultural production (Cullather 2004, 2007, 2010; Gordillo 2014; Gupta 1998; Howard 2016; Kinkela 2013; Kloppenburg 2005; Matson 2012; Olsson 2012, 2016; Otero 2013; Pearse 1980; Perkins 1997; Shiva 1991; Worster 1990). Agricultural and environmental scientists have examined the impacts of intensive $\mathrm{N}$ fertilization on crop yield and quality, and its effects in ecosystems worldwide (Aber 1995; Blumenthal et al. 2001; Brown 1999; Crews and Peoples 2004; Galloway 2001, 2002; Galloway et al. 1995, 2004; Mosier 2001; Mosier and Freney 2004). Concerned by the results for this work, they have proposed developing new technologies and management strategies that can increase Nitrogen Use Efficiency (NUE) and reduce N loss into the environment (Balasubramanian 2004; Cassman 2002; Galloway 2001, 2004; Holland et al. 1999; Horwarth 2002; Mosier and Freney 2004). NUE science and technologies may seem like yet another technocratic solution. However, in this article I argue that if combined with a sociopolitical and historical approach, studies on NUE and $\mathrm{N}$ management can help inform scientists and policymakers' efforts to improve better fertilizer use at local and regional scales. In particular, understanding the history of $\mathrm{N}$ use, policies, and knowledge networks casts light on how processes of state formation shaped the contours of contemporary socio-ecological issues, creating challenges for environmental protection beyond their spatial and temporal limits.

Today, Chile is one of the highest consumers of $\mathrm{N}$ fertilizer per hectare in the Americas, and it illustrates the positive and negative effects of Cold War politics on agricultural growth and the environment. Cold war politics encouraged $\mathrm{N}$ consumption, expanded $\mathrm{N}$ science, and integrated Chile's economy into global agricultural markets and knowledge networks. However, Cold War politics also disassembled formal communication channels between research institutions, farmers, and policy-making agencies that, had they existed, would have integrated and strengthened scientific knowledge on the negative ecological impacts of $\mathrm{N}$ loss. The first section of this article questions the triumphant narrative of the Green Revolution and fertilizer consumption and analyzes N's positive and negative effects. The second section analyzes Cold War politics that shaped $\mathrm{N}$ consumption and science after World War II. In the Cold War context, a transnational network of scientists, agencies, and authorities created an institutional framework to transfer knowledge and technology to Chile during the 1960s. Paradoxically, while this network was decisive in expanding $\mathrm{N}$ use and promoting the Green Revolution, it was also central in the subsequent development of a local science of $\mathrm{N}$ loss and its environmental impacts. The final section examines how scientists began raising the alarm regarding $\mathrm{N}$ pollution and its environmental effects. Nevertheless, as this case illustrates, the development of scientific knowledge on $\mathrm{N}$ loss and NUE has not been enough to develop better fertilization practices and environmental policies. A better understanding of the historical role of politics, institutions, and policies and how they are connected with expert communities may shed light on why this environmental science remains so disconnected from agricultural policies at local and regional scales.

\section{Nitrogen, the Green Revolution, and the dialectic of production and destruction}

In 1968, the Director of the US Agency for International Development (USAID) William S. Gaud coined the term "Green Revolution." Since then, the term has been used globally to describe technological improvements - in seeds, fertilizers, and pesticides, along with enhancements in irrigation and other mechanization processes - developed to increase agricultural production (Cullather 2004, 2010; Gupta 1998; Olsson 2012; Pearse 1980; Perkins 1997; Shiva 1991). Scholars credit this process of agricultural change with enabling export-oriented agriculture, such as that found in Ecuador (Partridge 2017) or Brazil (Hoelle 2017), and it has served as a model for the so-called "Blue Revolution" in aquaculture, as practiced in Chile (Gerhart 2017). 
The increasing use of $\mathrm{N}$ fertilizers remains central to the Green Revolution, worldwide. Between 1961 and 1988, global fertilizer consumption increased by 366\% (FAOSTAT 2016). Use of $\mathrm{N}$ fertilizers increased even more dramatically; in 2002, world $\mathrm{N}$ fertilizer consumption was $630 \%$ greater than in 1961 (see Figure 1). A decade later, in 2013, global $\mathrm{N}$ fertilizer consumption had increased $759 \%$ since 1961 (FAOSTAT 2016). Chile exhibits one of the steadiest increases in $\mathrm{N}$ fertilizer consumption per hectare ( $\mathrm{t} / \mathrm{ha}$ ) in the Americas since the 1960s (and especially since 1982), becoming the largest consumer in 2002. According to FAO, the average consumption of $\mathrm{N}$ fertilizer per hectare between 2002 and 2010 places Chile $16^{\text {th }}$ in the world ranking and first in Latin America. ${ }^{3}$

Scholars, farmers, and the general public generally agree that $\mathrm{N}$ fertilizers have been critical in feeding and clothing the increasing world population during the $20^{\text {th }}$ century (Bown 2005; Brown 1999; Cushman 2013; Perkins 1997; Smil 2001), and that they will remain important in the $21^{\text {st }}$ century (Galloway 2001, 2004; Horwarth 2002; Mosier and Freney 2004). Specialists argue that only half of today's population could have been supplied using pre-synthetic fertilizers, and even then only with overwhelmingly vegetarian diets. According to Smil (2001), pre-fertilizer farming could have only provided today's average diets to about 40 percent of the population. Experts estimate that $\mathrm{N}$ fertilizer has been responsible for about 40 percent of the increases in global grain yield since the 1960s (Brown 1999), and a critical factor in improving grain protein concentration (Blumenthal et al. 2001), and protein consumption across the globe since the 1950s (Cullather 2007).

However, this massive increase in synthetic $\mathrm{N}$ consumption has also negatively affected humans and the environment in ways that scientists and policymakers are only now starting to realize. The magnitude of $\mathrm{N}$ loss is a relatively recent discovery; scientists estimate that more than 60 percent of the annual $\mathrm{N}$ input into food production is not converted into usable product (Van der Hoeck, 1998). This surplus N, called "N loss" in the literature, is mostly dissipated into the wider environment causing a number of ecological side effects (Balasubramanian 2004; Galloway et al. 1995; Galloway and Cowling 2002; Mosier et al. 2004; Van Drecht et al. 2003). $\mathrm{N}$ pollution in watersheds and coastal ecosystems causes eutrophication and hypoxia-the excessive growth of algae, that results in oxygen depletion and the production of substances toxic to fish, cattle, and humans (Horwarth et al. 1996). It also generates acidification of lakes and streams (Evans et al. 2001) and soils (Crews and Peoples 2004; Kennedy 1992). And scientists report that the intensive use of $N$ fertilizers has increased GHG emissions at an average rate of 3.9\% per year from 1961 to 2010 (IPCC 2014; Tubiello 2013). At this rate, $\mathrm{N}$ fertilizers will become a larger source of emissions than manure in less than 10 years and the second largest of all agricultural emissions.

In sum, though it is clear that low levels of $\mathrm{N}$ in the soil can limit plant growth, a high percentage of $\mathrm{N}$ loss into the environment is triggering a sequence of negative environmental impacts through time and space, on a scale that challenges traditional disciplinary, geographical, and political boundaries (Erisman et al. 2013, 2015). In response, some scientists are working on methods to increase the efficiency of how $\mathrm{N}$ fertilizers are used (generally called "NUE" in the literature). Based on research into the global environmental effects of intensive fertilization practices, they are generating a new narrative that highlights the ecological limits of the Green Revolution, nodes of environmental destruction, and the socio-ecological dimensions of the so-called "Global Nitrogen Problem" or "Nitrogen Challenge." (Erisman et al. 2015) Although this kind of scientific knowledge has had an uneven effect on public debates and state policies during the last few decadesespecially in Latin America and other Third World regions - it has generated an entirely new approach to understanding $\mathrm{N}$ science and agricultural production.

\footnotetext{
${ }^{3}$ After Singapore, Qatar, Kuwait, Bahrain, New Zealand, Egypt, Trinidad and Tobago, Ireland, Luxemburg, Netherlands, China, United Arab Emirates, Republic of Korea, United Kingdom and Croatia. Data for Trinidad and Tobago between 2002 and 2010 from FAO was not included because of its high variability. Data represents tons of nutrients (N) per 1000 Ha. FAOSTAT 2016.
} 


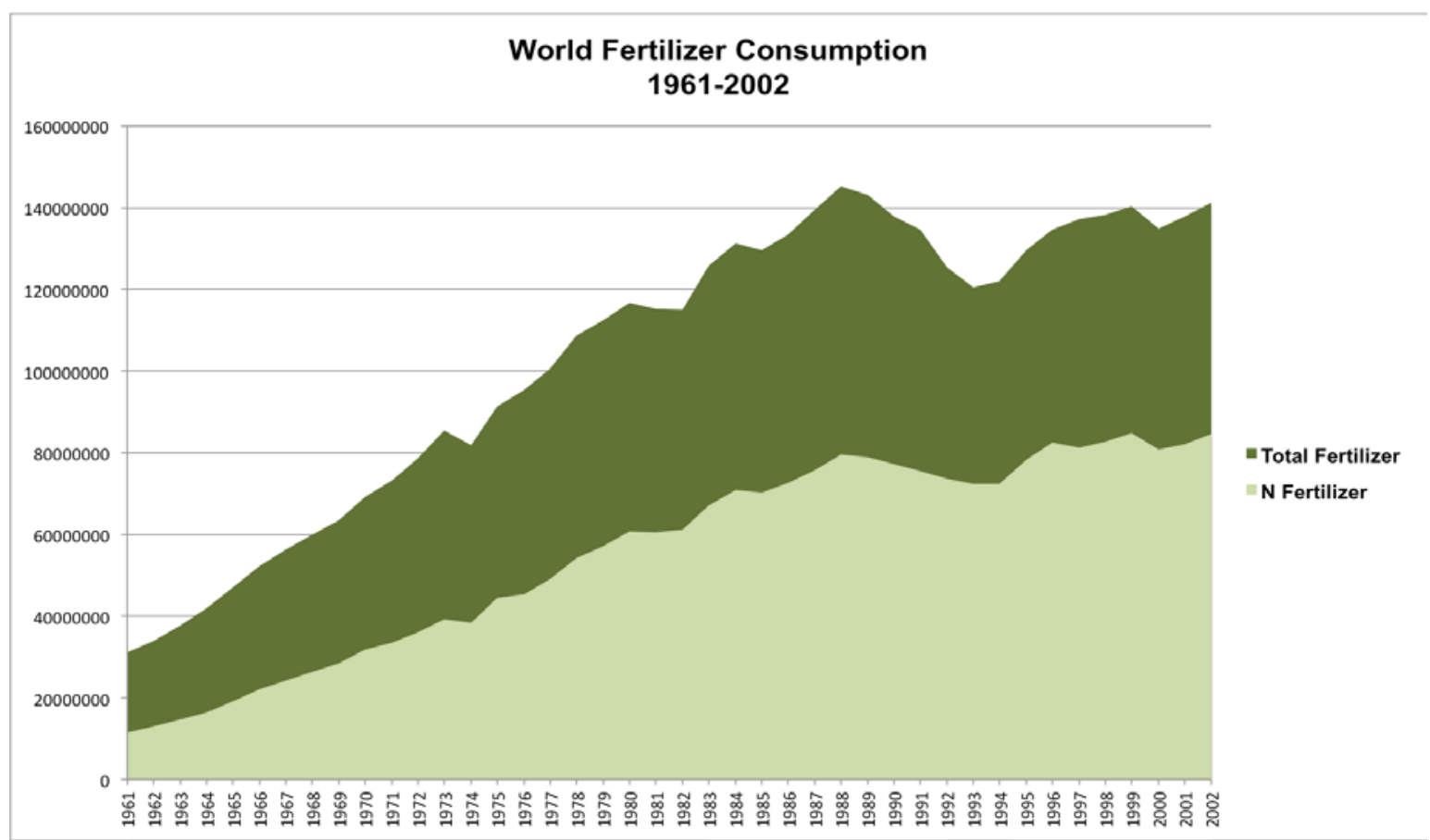

Figure 1: World fertilizer consumption, 1961-2002. Source: FAOSTAT, 2016. Data represents tons of nutrients.

\section{The transnational politics of agricultural modernization and the Cold War}

Although fertilizer access has been central to feeding and clothing a growing global population, there was nothing inevitable about soil exhaustion and fertility in this process of agricultural change. It results from a complex web of political, social, and economic factors operating at local and global scales. Historians have analyzed how agricultural production became broadly "institutionalized" and "politicized" since the 1920s and particularly after World War II (Fitzgerald 2003; Johnson 2016; Muir 2014; Olsson 2016); while some have debated this process as part of a broader project of "Americanization" (Olsson 2016), and others have highlighted the importance of dissimilar experiences in China, the Soviet Union, or India (Gupta 1998; Schmalzer 2016; Smith 2014). Cold War historians have in the last decade revitalized studies of technological and political change in farming (Cullatter 2010; Kinkela 2011; Perkins 1997; Staples 2006). Still, few of these works focus specifically on fertilizers, despite their importance to agricultural production and ecosystem destruction, and few analyze these dynamics in Latin America (cf. Bown 2005; Gorman 2013; Leigh 2004; Smil 2001).

Since early human history, farmers have known about the importance of soil nutrients and have sophisticated practices for managing nutrients, soils and crops (Bown 2005; Cushman 2013; Gorman 2013; Melillo 2015; Muir 2014). However, at the start of the $20^{\text {th }}$ century, land-use practices and a growing global population rendered natural rates of $\mathrm{N}$ fixation and organic and mineral fertilizers insufficient (Erisman and Vries 2015; Galloway and Cowling 2002; Gorman 2013; Keeney and Hatfield 2008; Perkins 1997). Rather than emphasize soil exhaustion and the needs of a growing population, here I argue that $\mathrm{N}$ fertilizer became so popular during the second half of the $20^{\text {th }}$ century because of agriculture's new role in international politics, and a Cold War politics that dominated debates over fertilizer access and consumption. 


\section{Hunger, Communism, and Cold War politics}

Throughout the $20^{\text {th }}$ century, food access-and consequently agricultural production-became a central issue in international politics. After the Second World War, Western European states and the United States understood that agricultural production must be fully integrated into government planning efforts, as a factor in conflict and even war. Agricultural sciences became considered as essential to building food production systems and thereby the military and economic strength of a nation (Perkins 1997: 85). Politicians and institutions considered agriculture as a central instrument in nation-centered international politics (Perkins 1997: 103).

In 1941, Franklin D. Roosevelt's State of the Union Address famously listed four "essential human freedoms": freedom of speech, freedom of religion, freedom from want, and freedom from fear. The third freedom, "freedom from want", set a new moral role for the United States and Western Europe in improving food access in poorer nations, thus catapulting agriculture into international politics (Donohue 2003; Muir 2014; Office of War Information 1942). Roosevelt's four freedoms were integrated into the United Nations Universal Declaration of Rights, helped motivate the creation of the UN Food and Agriculture Organization, and informed the agenda of institutions like the World Bank and the World Health Organization (Muir 2014). Under this rubric, hunger and what came to be known as the "World Food Problem" became central issues in international politics (Cullather 2010; Ekdladh 2011; Perkins 1997; Staples 2006).

Cold War politics, however, provided food production and hunger with a different ideological dimension. International policies supporting agricultural development in Third World regions became another front against the perceived threat of communist regimes. Hunger was a symptom of overpopulation and resource exhaustion, which in turn as thought to create further resource pressures and political instability (Perkins 1997, 119; cf. Unger and McNeill 2010). In 1951, the Rockefeller Center's Mexican Agricultural Program, produced an article entitled The world food problem, which reflected the new role of agricultural technology and production in Cold War politics. It argued that:

...agitators from Communist countries are making the most of this situation [hunger and resource exhaustion]. The time is now ripe, in places over-ripe, for sharing some of our technical knowledge with these people. Appropriate action now may help them to attain by evolution the improvements, including those in agriculture, which otherwise may have to come by revolution. (Rockefeller Foundation 1951)

By the 1950s, in the United States and Western Europe agriculture had been integrated into government efforts to construct national food production systems, and technical and scientific agricultural knowledge had become a strategic instrument to defeat communism. Cold War politics understood agricultural production, technologies, and agrarian reforms as central to the development of better social and economic conditions in the countryside. If underdeveloped countries could experience higher living standard conditions through the adoption of technology, the potential for achieving those reforms through revolutionary means would be drastically reduced. Thus the "feeding the world" argument—used even today by advocates of a triumphant narrative about the Green Revolution-is in part a product of this ideological framework which understood food access and agricultural production as a critical dimension of international relations during the Cold War.

\section{The "soil fertility problem" and a transnational framework for agricultural development}

Meanwhile, in Latin America, international development professionals quickly translated the connection between agricultural production and Cold War politics into a problem of "soil fertility." This created a privileged arena for the development of soil and plant sciences, technology transfer, and the subsequent expansion of fertilizer consumption. However, the institutional response to the problem of soil fertility was not soil conservation, and it did not consider the natural limits of soil biochemistry demonstrated by some soil scientists and other advocates (Muir 2014: 128). Instead, the response only involved increasing use of fertilizers. 
Several international meetings on soil fertility and fertilizer access occurred during the late 1940s and 1950s in Latin America. The Joint UN Food and Agriculture Organization (FAO) - Economic Commission for Latin America and the Caribbean (ECLAC) Working Party on Agricultural Requisites in Latin America convened in May 1949, in Mexico City. This meeting provided the starting point for defining the "soil fertility problem" in the region. The Joint Working Party Report emphasized that "soil and fertilizer experts in Latin America were generally concerned that soil fertility levels were declining and, in many soil areas, plant nutrients were not being adequately restored" (FAO 1953: 2). In the following years, several meetings were held in Ecuador, Uruguay, Brazil and Costa Rica (FAO 1953, 1957; FAO-ECLA 1950; FAO-UNESCO 1971). These brought together national and international institutions, such as FAO, the Inter-American Institute of Agricultural Sciences of the Organization of American States, and local governments, to collaborate on expanding agricultural sciences and implementing programs to increase fertilizer consumption. For instance, during the 1960s, within the Alliance for Progress, several agricultural development programs were established between Latin American governments, international organizations, and the United States. ${ }^{4}$ At the same time and following the model of state agricultural planning, Latin American governments established national agricultural research institutes in cooperation with other public institutions and universities. In the late 1950s Argentina and Ecuador were the first to introduce this model. Throughout the 1960s the majority of Latin American countries developed similar institutions, often with technical and financial support from foreign agencies (Stads 2009). Similarly, private or semi-private organizations were also established during these decades and were critical to expanding agrochemical industries in the region (Ross 2000). ${ }^{5}$

As "soil fertility" and agricultural production became central political problems, an institutional framework to expand agricultural sciences, mechanization, and access to agrochemicals was created by these national and international organizations. Local actors utilized this international framework to develop research institutions, expand the dissemination of knowledge and resources, and to dramatically transform the social and material conditions of agricultural production in the countryside. In doing so, however, they not only contributed to the creation of a global agricultural system, they also re-formulated in unexpected ways some of the basic assumptions and goals of the Green Revolution as a tool of the Cold War.

\section{Chile's agricultural transformation and the local politics of the Green Revolution}

Recent scholarship on the agricultural economics of the "Chilean miracle" that occurred during the dictatorship of Augusto Pinochet (1973-1990) suggests that earlier international and national efforts laid the groundwork for the subsequent and rapid expansion of Chile's agricultural industry (Jarvis 1985, 1989; Klubock 2014; Melillo 2015; Tinsman 2014; see also Gerhart 2017). Since the early $20^{\text {th }}$ century, Chile looked to the United States as a future market for its agricultural products and as a model for its agricultural industries (Tinsman 2014).

It was during the 1960s, however, that Chile developed an institutional structure that would prove key for further modernizing agricultural practices and science over the coming decades. The support of foreign aid, particularly from USAID and the Rockefeller and Ford Foundations, was also important. As part of the

\footnotetext{
${ }^{4}$ The US Agency for International Development was established in 1961 under John F. Kennedy's administration, and along with the Ford and Rockefeller Foundations, was key in this process. The International Maize and Wheat Improvement Center (CIMMYT) was formally established in Mexico in 1966. The Mexican Agricultural Program (MAP) was one the first established in the second half of the 1940s and worked as model for other similar programs in Colombia, Chile, Central America, the Philippines, and India created by the Rockefeller Foundation, the Ford Foundation and USAID (Olsson 2012). CIMMYT, along with the International Rice Research Institute (IRRI) established in the Philippines in 1959 by the Ford and Rockefeller Foundations, were icons of the international effort to produce what later became known as the Green Revolution.

5 American and German investors founded the Atlantic Development Group for Latin America (ADELA) in 1964, supporting several agricultural businesses between 1965 and 1980. Under the support of President Lyndon B. Johnson, the Agribusiness Council (ABC) was formed in 1967 in order to facilitate American agribusiness's participation in agricultural programs with developing countries. In 1969 European and American shareholders, among them Bank of America, Caterpillar Tractor Company, Gerber Products and Monsanto founded the Latin American Agribusiness Development Corporation (LAAD) (Ross 2000).
} 
mission to reduce support for communism, and under explicit pressure from the Kennedy administration, Jorge Alessandri's conservative government (1958-1964) undertook the first land reform in 1962. Expanded in 1967, these reforms began as an effort to simultaneously break up the system inherited from the colonial period, encourage capitalism, and prevent communism. Reforms included efforts to boost food production through mechanization, organize landholders into cooperatives, and develop greater access to agrochemicals such as fertilizers and pesticides (Tinsman 2014: 38).

Alessandri's successor, Eduardo Frei Montalva (Christian Democrat, 1964-1970) continued this model of agricultural development. His administration viewed state-led projects, the increase of local production, and insertion into global markets as central to economic and social development. In 1964, INDAP, CORFO, and three major national universities founded the National Institute for Agriculture and Livestock Research (INIA), which remains the premier state-led agricultural research institution and one of the key actors in enhancing agricultural sciences at a national level (Venezian 1987, 1993; Venezian and Muchnik 1995). In 1965, as part of the wider mission of the U.S Alliance for Progress to speed Latin American modernization and to prevent communism, the University of California and the University of Chile entered into a cooperative agreement (the Chile-California Convenio). The program, mostly funded by the Ford Foundation, emphasized agriculture, veterinary medicine, and the natural sciences, and provided for the mutual exchange of faculty members and graduate students. The Chile-California Convenio was part of two other cooperation programs established between 1963 and 1967. They were the most successful bilateral international agreements transforming agricultural sciences and research in Chile (Bauer and Catalán 2016; Jarvis 1994; Tinsman 2014; Venezian 1993). Almost one third of the exchanges came from the departments of agricultural sciences at the University of California, Davis (Tinsman 2014: 42). Specialists consider today the so-called "Davis boys" key agents in the development of Chile's agricultural sciences and technologies since the 1960s (Jarvis 1994; Melillo 2015; Tinsman 2014). ${ }^{6}$

During the 1960s and early 1970s, authorities considered the main areas for agricultural development to be through interagency and international cooperation, financial and technical assistance to farmers, and coordination between research institutions and universities (Bauer and Catalán 2016; Venezian 1987, 1993). This transnational framework for the transfer of knowledge and technology dramatically increased public funding for agricultural research, technological transfer, and fertilizer access (Venezian 1987, 1993). In 1960 and 1965, Presidents Alessandri and Frei Montalva made adjustments to the fertilizer subsidy program created in 1952 to reduce prices and increase consumption. In 1967, Frei Montalva's government drastically transformed fertilizer access by allowing the Chilean state-run bank (Banco del Estado) to start imports of Urea and other ammonia-based fertilizers (Valdés 1976). As a result, N consumption doubled between 1962 and 1973; the high watermark from this period was only reached again in 1982 (FAOSTAT 2016).

The postwar role of agriculture in government planning and international politics expanded Chile's institutional structure, government funding and coordination, and agricultural sciences and technologies through the model of American state-led modernization that dated back to the 1920s, and its public reforms since the 1960s. Paradoxically, as Chilean authorities, scientists, and technocrats reshaped international projects aimed at defeating communism, these took on a life of their own, increasing demands for technological change and for the state to play a more active role in agricultural modernization. In this context

\footnotetext{
${ }^{6}$ Academic exchange with the University of California continued until 2008 when the program was re-named the "ChileCalifornia Plan: Partnership for the 21st Century." As part of this longstanding scientific and academic exchange, the Chile-California Council (created in 2011), the General Consul of Chile in San Francisco, and the Chilean Students' Associations at the University of California Davis, Berkeley, and Stanford University organized four annual meetings between 2012 and 2015. The 'Chile-California Conference', or 'C3', aimed to bring together scholars and researchers from both regions and to discuss common challenges in public education, innovation, health, sustainability, and agriculture (http://chile-california.org/projects/chile-california-conference). In 2014, the Chilean Students' Associations at the University of California Davis organized a conference to discuss the historical cooperation between Chile and UC Davis in agriculture and veterinary medicine (http://www.chileatucd.com/chile-ucd-conference-2014.html). In 2015, as part of an initiative from the Chilean Government and the University of California's program of internationalization, UC Davis installed a Life Science Innovation Center in Chile. Today the center focuses on the transference of science and technology in the agricultural-food sector, and aims to develop collaborative projects between UC Davis and universities and agribusiness in Chile (http://www.ucdavischile.org/en/home).
} 
of social and state-led technological change, the socialist Salvador Allende won the 1970 Presidential election. For conservatives and the United States Government, this was an undesirable victory. Despite the turn to the political left, it was also a triumph for state-led agricultural development. The transnational institutional framework established in the 1960s and early 1970s created the basis for the development of the agricultural sector and sciences for the following decades. It generated institutions and relationships that integrated Chilean scientists into global networks of knowledge production that had been critical to the increase in fertilizer consumption and the expansion of $\mathrm{N}$ science during the 1960s. But it also offered a privileged platform for the continued development of the science of $\mathrm{N}$ loss from the late 1980s.

\section{Global nodes of rubble and the limits of the Green Revolution}

As in the United States, Chilean scientists quickly understood the political role of $\mathrm{N}$ science for the country's agricultural and economic development. By the late 1960s and early 1970s, they had incorporated the language and even the concept of the Green Revolution (cf. Raggi 1969). By understanding the role of N science in terms of "development", "progress", and even "patriotism", Chilean scientists created a central justification for the expansion of scientific knowledge on nitrogen-plant dynamics, the incorporation of international scientific knowledge and methods, and the expansion of "efficient" and "rational" fertilization practices at the local scale.

Unexpectedly, this boom in $\mathrm{N}$ science also created a privileged arena to develop better estimations of $\mathrm{N}$ loss into the environment. Although environmental issues were not necessarily part of these initial concerns, the collection of systematic scientific knowledge during the 1960s and 1970s became the basis for the rise of environmental awareness in Chile during the late 1980s. Paradoxically, the institutional channels for transferring knowledge, technologies, and resources created during the Cold War to expand fertilizer consumption and agricultural sciences also generated a scientific platform to assess the ecological impacts of $\mathrm{N}$ fertilization.

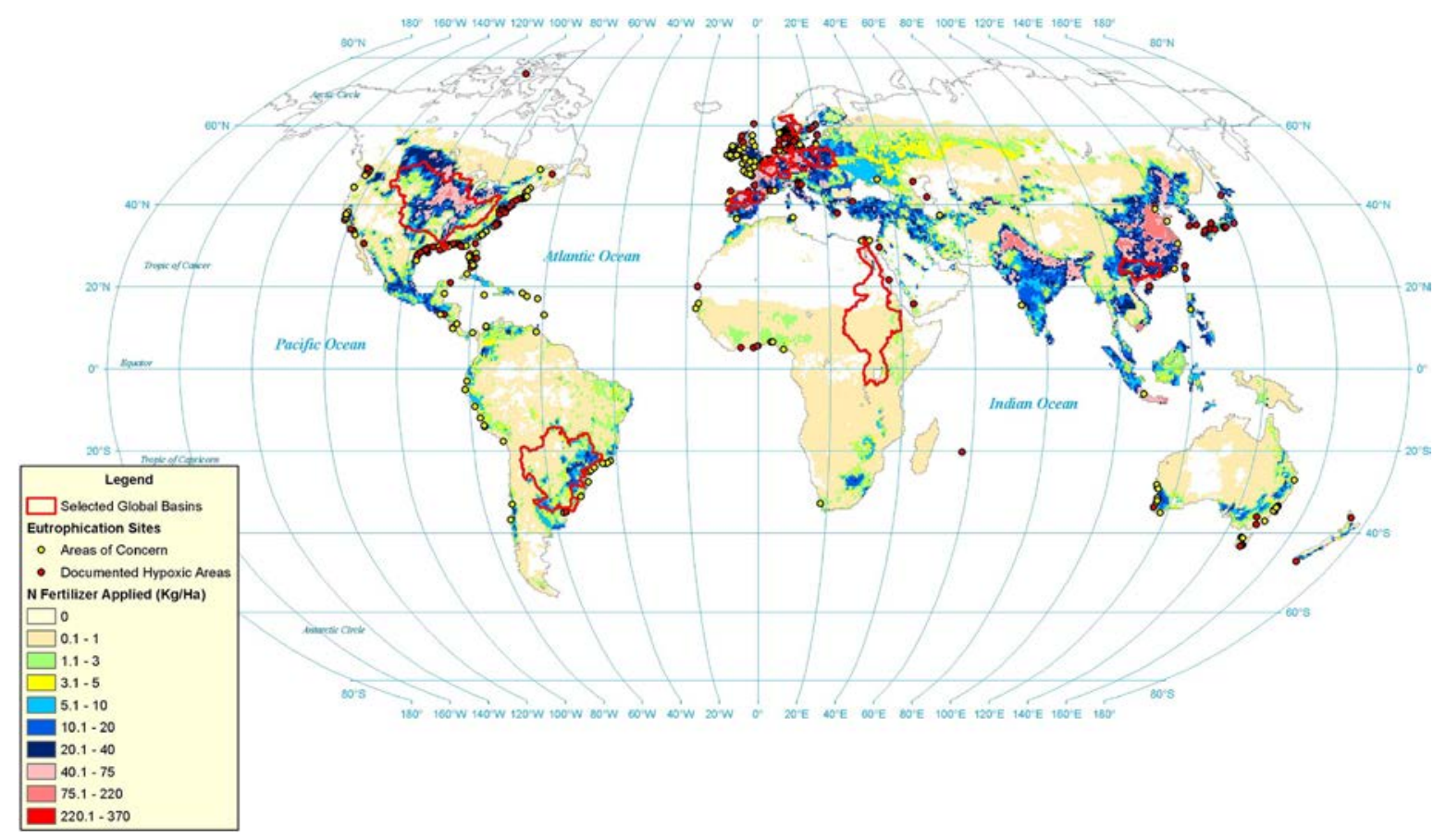

Figure 2: Hotspots of N application and eutrophication sites. Source: Potter et al. (2009). 


\section{$N$ loss and global environmental awareness}

An international community of scientists had been advancing understanding of the positive effects of $\mathrm{N}$ fertilizer on agricultural production since the 1960s. But they also began to ask questions about the fate of $\mathrm{N}$ fertilizer that was not absorbed by plants and, subsequently, how to build a better understanding of the biochemical processes involved in $\mathrm{N}$ loss and its effects on ecosystems. ${ }^{7}$ In doing so, they started building a narrative about global nodes of rubble derived from intensive $\mathrm{N}$ fertilization, thereby highlighting some of the environmental limits of the Green Revolution.

In the United States in the late 1970s, and in Chile a decade later, the scientific debate about "efficient" and "rational" fertilizer use became more than an economic problem. It was also an environmental and social one (cf. Gorman 2013). Although scientific knowledge on N use efficiency and N loss has had an uneven effect on public debates and state policies regarding $\mathrm{N}$ fertilizers—especially in Chile-it has generated a new approach to understanding global agricultural production. Today scientists have a more complete understanding of the processes involved in $\mathrm{N}$ uptake by plants; natural and human drivers (industrial and biological $\mathrm{N}$ fixation); and the biochemical processes leading to Ammonia $\left(\mathrm{NH}_{3}\right)$ volatilization, Nitrate (NO3) leaching into soils and groundwater, and the liberation of Nitrous Oxide $\left(\mathrm{N}_{2} \mathrm{O}\right)$, Nitric Oxide (NO), and Nitrogen Gas $\left(\mathrm{N}_{2}\right)$ into the atmosphere (Jenkinson 2001; Peoples et al. 2004; Van Drecht 2003; Vitousek et al. 1997, 2002). They have better estimates of the amount of $\mathrm{N}$ fertilizer used in global agricultural production that is effectively absorbed by crops as well as the excess that remains in soil, groundwater, and the atmosphere.

Figure 2, for instance, shows global sites with high rates of $\mathrm{N}$ fertilizer application per hectare (reported between 1994 and 2002) that are also associated with polluted coastal ecosystems (reported eutrophication and hypoxia). Human-driven eutrophication from excessive fertilization practices is considered one of the main drivers of nutrient overloading in coastal and inland aquatic ecosystems, although excessive growth of algae and the resulting oxygen depletion can also be a natural process. The map highlights intensive $\mathrm{N}$ fertilization rates per hectare in several places: the Midwest in the United States, the Gulf of Mexico, India, Western Europe, and Southern Brazil. In Chile, the map points out the so-called Central Valley, the region in Chile with the most intensive agricultural practices, running from Coquimbo in the north to Chiloé in the south (on other environmental issues in this region see Gerhart 2017). ${ }^{8}$

With maps like this one, scientists are synthetizing their knowledge of global nodes of $\mathrm{N}$ pollution and the emergence of what have been called "dead zones" in aquatic ecosystems. ${ }^{9}$ Identified from a combination of biochemical processes in soils, watersheds, the atmosphere, and human actions, these nodes of ecological destruction do not necessarily follow national borders, and affect communities, economies, and social and political dynamics in ways that scholars still need to study. The "hotspots" or "dead zones" are regions of $\mathrm{N}$ "overuse", and illustrate the ecological effects of intensive $\mathrm{N}$ fertilizer use. As part of this process of global environmental awareness, during the last decade scientists, policy-makers, and stakeholders have contributed to the creation of "Nitrogen Assessments" in Europe and the United States. These assessments have synthesized the scientific knowledge on fertilization practices and $\mathrm{N}$ pollution and make recommendations for more efficient management practices at national and regional scales (EPA 2011; Sutton 2011; Tomich et al. 2016). Scientists also recently elaborated the concept of a "nitrogen cascade" to describe how a single atom of reactive anthropogenic $\mathrm{N}$ can trigger a sequence of negative environmental impacts through time and space on a scale that challenges traditional disciplinary, geographical, and political boundaries (Billen et al. 2013; Erisman et al. 2015; Galloway et al. 2003). As part of this process, recent international scientific meetings have reinforced the need for a global understanding of the $\mathrm{N}$ problem, and

\footnotetext{
${ }^{7}$ See Table 1 in Galloway et al. (2013) and Gorman (2013).

${ }^{8}$ For a map of main Chile's agricultural regions see Venezian (1987: 2).

${ }^{9}$ A similar world map of eutrophication and hypoxia including locations reported from 1950 to 2010 can be found here: http://www.wri.org/media/maps/eutrophication/fullscreen.html.
} 
the importance of incorporating a multi-scale and multi-disciplinary approach to manage what many consider is the "carbon" of the $21^{\text {st }}$ century. ${ }^{10}$

Agricultural sciences and policies in Chile after 1973

A military junta supported by the United States and conservative sectors of society took power in Chile on September 11, 1973, and moved quickly to restructure the country politically and economically. Major economic policy changes were implemented to reduce government intervention, increase the role of markets in the allocation of resources, and encourage private initiative and investment. By strengthening market-based policies for agricultural development and diminishing the role of the state in coordinating the transfer of technologies and resources, the post-1973 Chilean state dismantled an institutional framework that could have been critical in linking the science of $\mathrm{N}$ loss into agricultural practices and policies.

The military regime systematically denied resources-technical assistance, credit, machinery, and irrigation infrastructure - to the small farm subsector, which had been a major beneficiary of agrarian reforms under Presidents Frei Montalva and Allende. This reflected the military regime's political convictions and free market orientation, as well as their view that large farms were inherently more efficient, and that small farmers would be incapable of learning the technicalities of business and modern agricultural production (Jarvis 1985: 5, 29). According to Robert Gwynne and Cristobal Kay, the legacy of the military government's agricultural policies was inequality. In a system where government avoided giving direct assistance through credit or extension services, large-scale commercial farmers who had access to private investment were most successful at achieving technological change (Gwynne 1998; Gwynne and Kay 1997; Jarvis 1994; Kay 2002).

The emphasis on market-based policies and the weakening of the state's role as coordinator created a system where research institutions had limited formal mechanisms to connect their science with agencies planning agricultural policies. The military government rapidly replaced INIA's Board of Directors, which originally included the Deans of the four major colleges of agriculture, for a president appointed as an "intervenor" (Venezian and Muchnik 1995). The Pinochet administration intervened in universities by "designating" military officers as presidents (rectores), who made significant changes in personnel, curriculum, and other areas. As part of these reforms, the government drastically reduced public expenditure on agriculture, higher education, and research (Venezian and Muchnik 1995). In this new political context, the Ford Foundation ended its support of the Chile-California Convenio soon after the military coup (Bauer and Catalán 2016). As result of these reforms, universities, research institutions like INIA, and policymaking agencies had no formal communication channels for the transference of knowledge or technology (Venezian 1993). This process of institutional dis-assemblage also affected work on other environmental issues (Barandiaran 2015; Carruthers 2001; Tecklin et al. 2011).

The reduction in public expenditure shifted the funding base for agricultural research from regular budgetary allocations to competitive grants. These grants required the private sector to be involved through counterpart funding or collaborative research and were open to all research institutions. Thus, most of the agricultural research community had to compete for funds with all other science and technology groups in the country (Venezian and Muchnik 1995). In 1981, Pinochet's government created the National Fund for Scientific and Technological Development (FONDECYT). Administrated by the National Commission for Research, Science, and Technology created under Eduardo Frei Montalva's government in 1967, FONDECYT has since been the main funding source for scientific research on $\mathrm{N}$ science and agriculture. That same year, Pinochet's Ministry of Agriculture created the Foundation for Agricultural Innovation (FIA). These institutions have sponsored over $90 \%$ of the state funded projects studying $\mathrm{N}$ fertilization, $\mathrm{N}$ loss, and sustainable agriculture in Chile since 1981 (see Figure 3).

\footnotetext{
10 See Ling et al. (2016) and reports from the 7th International Nitrogen Initiative Conference (INI) in 2016 (http://www.ini2016.com).
} 


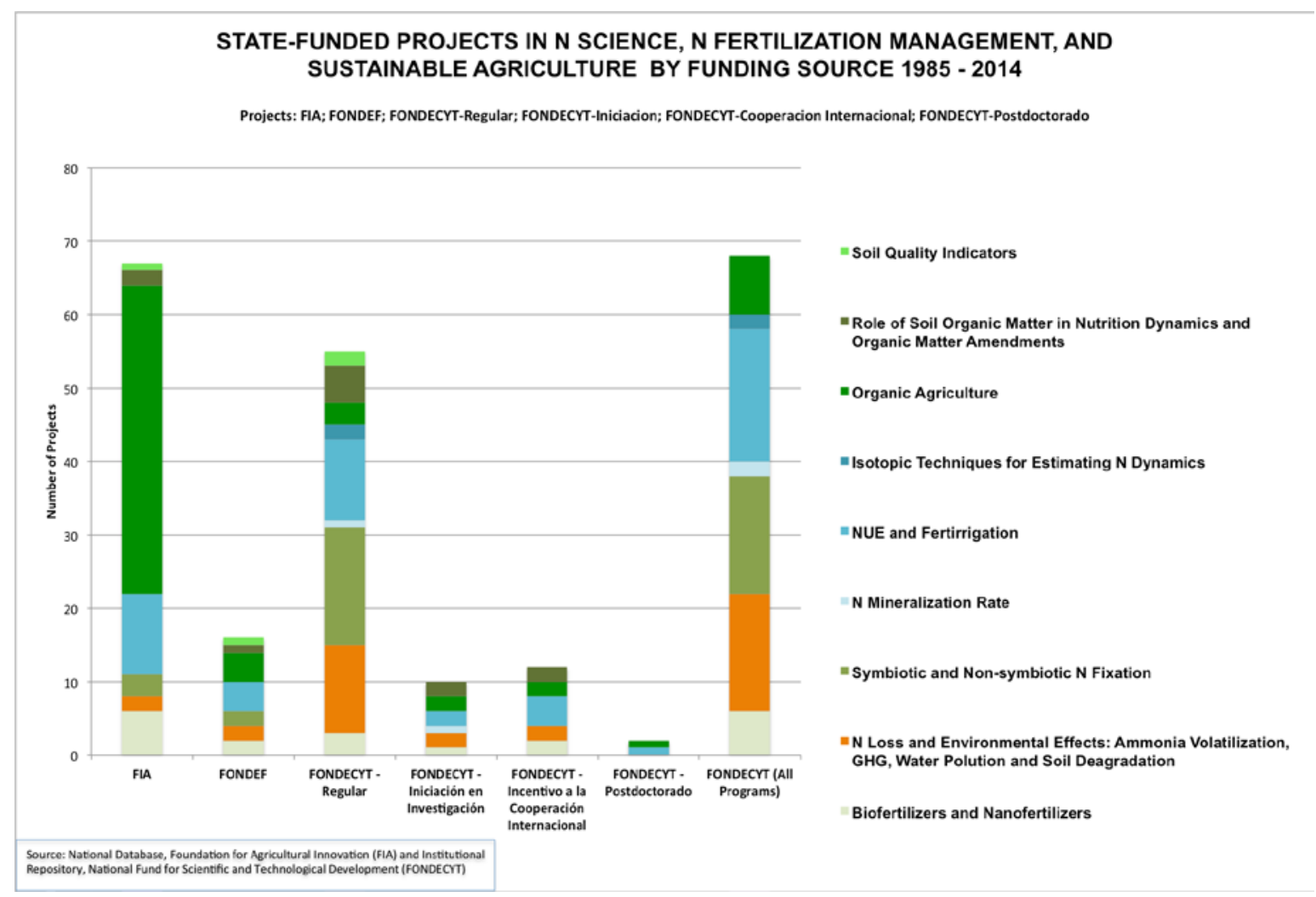

Figure 3: State-funded projects in $\mathrm{N}$ science, fertilization management, and sustainable agriculture in Chile 1985-2014.

FONDECYT, FIA and FONDEF (Fund for the Promotion of Scientific and Technological Development, created in 1992 under democratic President Patricio Aylwin) have concentrated all government spending in projects about $\mathrm{N}$ related sciences and $\mathrm{N}$ fertilization in Chile over the last three and half decades. The creation of FIA and FONDECYT, however, did not significantly transform state-funded research during the 1980s. Instead, budgets for projects in these areas remained extremely limited until the second half of Patricio Aylwin's term (Figure 4).

Undoubtedly, the study of $\mathrm{N}$ loss into the environment and its effects remains limited in Chile compared to the United States and Europe. However, Chilean scientists gradually started studying different mechanisms of $\mathrm{N}$ loss in the late 1980s through undergraduate, masters, and doctorate theses and dissertations. After 1973, institutions like INIA remained central to scientific work on N loss and state-funded projects expanded this research in universities during the 1990s and 2000s (see Figure 5).

However, despite the increasing scientific knowledge about $\mathrm{N}$ loss and its impacts in Chile, scientists have failed to unify this knowledge into a cohesive or national format that could inform policy and scientific practice. Although the scientific production on $\mathrm{N}$ loss and its environmental effects is growing, materials synthesizing this knowledge on a regional or national level that could educate authorities and producers are almost nonexistent. Likewise, despite the significant role of the state in allocating resources, the Chilean state has not been able to create efficient institutional means to translate science into policies. Nor has it been able to rebuild effective communication between government-supported institutions conducting research in these areas (for example, INIA) and policymaking agencies (like The Government's Office of Agricultural Policy, ODEPA). After the return of democracy, governments during the 1990s and 2000s maintained and even broadened Chile's exposure and participation in international markets, and avoided regulations that might 
limit national economic development. On social and economic issues, the first democratic governments inherited a weak state and therefore decided to increase the state's role in these areas gradually (Gwynne 1998; Gwynne and Kay 1997; Kay 2002; Silva 1996).

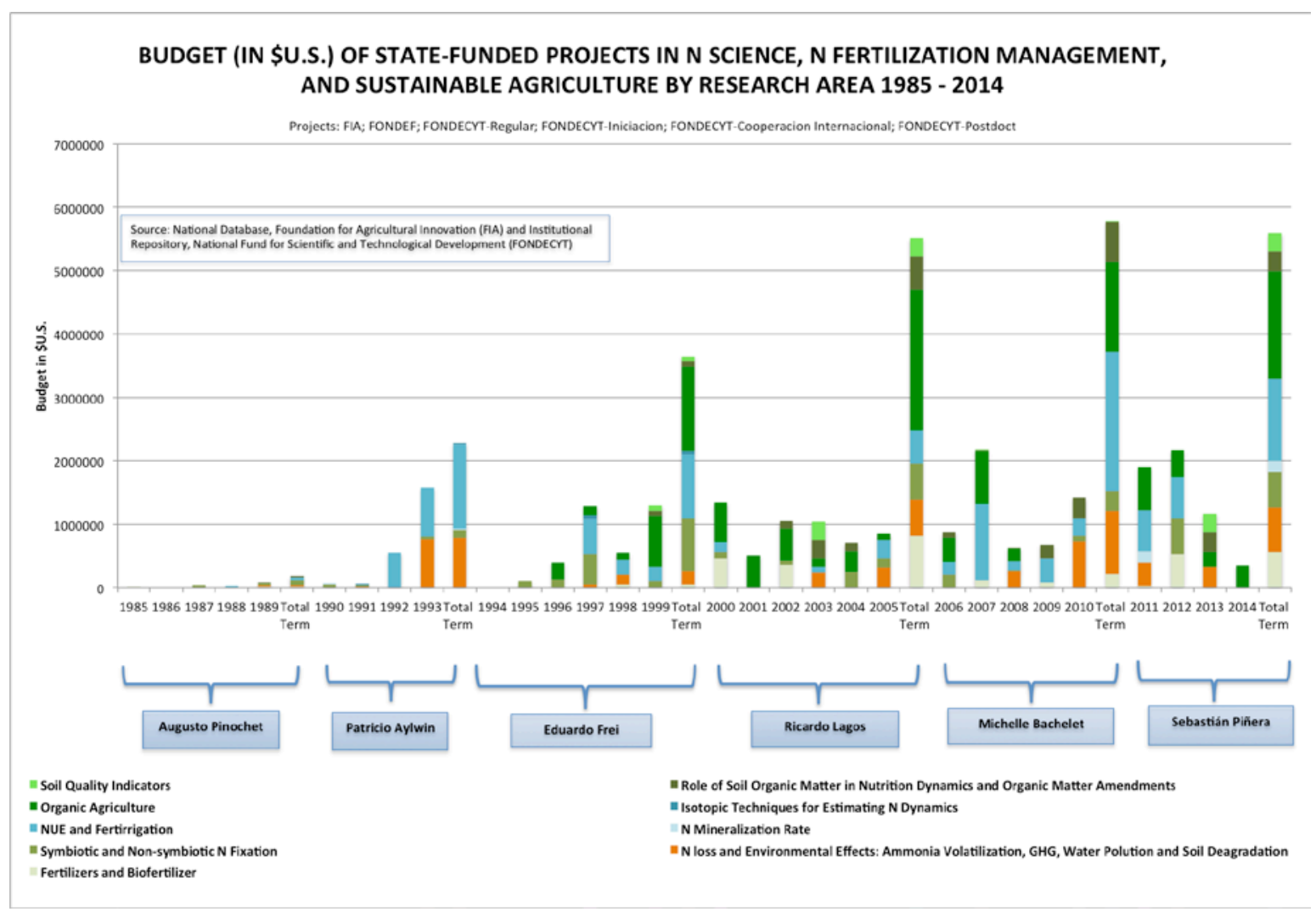

Figure 4: Budget of state-funded projects in N Science, fertilization management, and sustainable agriculture by research area in Chile 1985-2014.

\section{Conclusion: towards an integrated approach to the global Nitrogen problem}

Although the science of $\mathrm{N}$ loss and its environmental effects has grown in Chile since the late 1980s, a synthesis assessing major nodes of destruction and their reach is still needed. Local and international scientists have identified coastal eutrophication and hypoxia in Chile's central valley, but better estimations are needed to study underground water and coastal pollution and GHG emissions. ${ }^{11}$ A critical approach to $\mathrm{N}$ science and policy requires a better scientific understanding of the dialectic of production and destruction within the national agricultural industries, particularly their economic and political drivers and socioecological consequences. However, to increase the efficient use of $\mathrm{N}$ fertilizers and generate new models of

\footnotetext{
${ }^{11}$ In 2010, Chile voluntarily agreed at the UN Framework Convention on Climate Change to reduce GHG emissions from agriculture by $20 \%$ for 2020 . As part of this agreement, Chile launched a national program for climate change mitigation in agriculture and a national inventory of GHG emissions (Programa Nacional para la Mitigación del Cambio Climático en Agricultura y Mejoramientos del Inventario Nacional de Gases de Efecto Invernadero). Scientists from INIA and other institutions are currently conducting research to quantify and reduce GHG from agricultural practices and elaborate a first national plan for mitigation (NAMA) for the agricultural sector. (http://www.inia.cl/proyecto/502450/; http://www.inia.cl/blog/2015/09/28/estrategias-de-manejo-agronomico-contribuiran-a-mitigar-las-emisiones-de-gasesefecto-invernadero/)
} 
agricultural production while protecting the environment, Chile also needs to rebuild an institutional framework which will be critical in connecting scientific production with policymaking agencies.

From a global perspective, enhancing the technical and economic efficiency of $\mathrm{N}$ fertilizers is essential for both agricultural production and protection of the environment. With little new land suitable for crop production, the output per unit area must increase to meet the expected world population of 8.9 billion people by 2050 (FAO 2004). If NUE is not improved, marginal lands will be brought into production resulting in increasing land degradation that will affect both production and the environment (Cassman et al. 2002; Mosier 2004). In fact, even greater rates of $\mathrm{N}$ loss from global food production are likely in the future, as the human population and the demand for animal protein increases (Galloway et al. 2002). The anthropogenic Nfixation rate is expected to increase by roughly $60 \%$ by the year 2020 , primarily due to increased fertilizer use and fossil-fuel combustion (Galloway et al. 1995). ${ }^{12}$

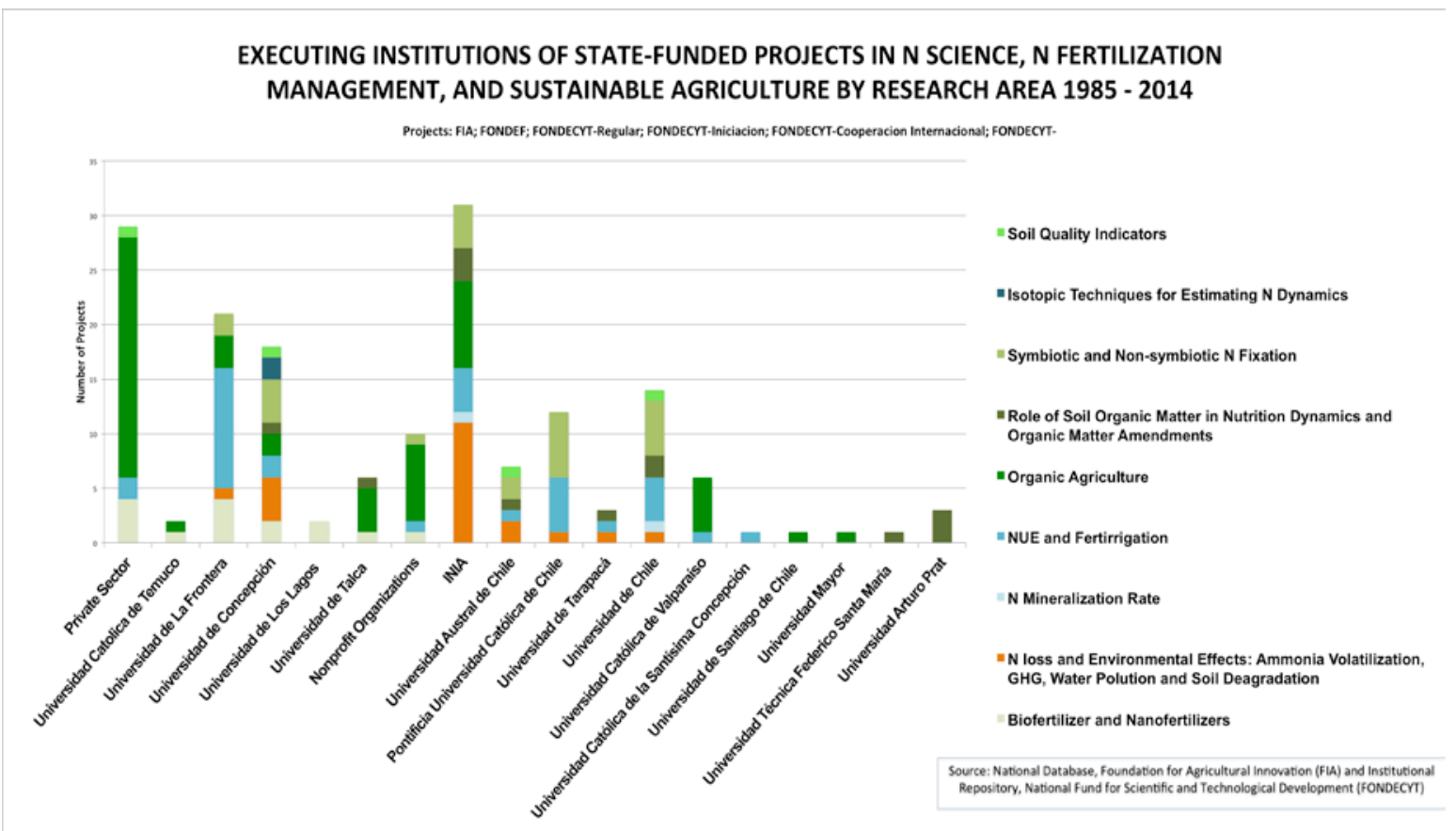

Figure 5: Executing institutions for state-funded projects in $\mathrm{N}$ science, fertilization management, and sustainable agriculture by research area in Chile 1985-2014.

Considering that current $\mathrm{N}$ loss into the environment and the potential to improve NUE depend on natural, technological, economic, and political processes, scholars have called for an integrated approach (Galloway et al. 2002). In particular, further technological and economic tools to better develop integrated $\mathrm{N}$ and irrigation management strategies are central to face the $\mathrm{N}$ challenge and to reduce $\mathrm{N}$ losses into the environment. I contend, however that the current scientific and political concern regarding $\mathrm{N}$ pollution and efficiency requires a better understanding of the socio-economic and political factors that have determined our existing agricultural practices and policies at a local and regional scale. This includes the historical role of national and transnational institutions and government agencies, scientific knowledge, and communication channels between expert communities and policymaking agencies, discussed in this article. As we begin a

12 Indeed, scientists believe that current levels of NUE remain well below what could be achieved with improved technologies (Cassman et al. 2002). 
new stage in the history of inter-American relations and potentially, a lesser role for the United States in international environmental protection from 2017, I argue that the expansion of national and transnational frameworks for the transference of knowledge will be fundamental for enhancing environmental science and policy on a local and global scale.

History and social sciences are critical in this process, as a crucial means to assess the human actions behind the current and future standards of $\mathrm{N}$ fertilization. ${ }^{13}$ Environmental protection and agriculture policies on NUE require an integrated approach to science, politics, and policy as well as a better understanding of the past and present dynamics shaping our current models of agricultural production. The humanities and social sciences have played a critical role in building a narrative about the politics and economics of human-induced environmental change, but much remains to be done to connect these conclusions and approaches with the general public and policymakers at local and global scales.

\section{Acronyms}

$\mathrm{ABC}$ :

ADELA:

Agribusiness Council

CIMMYT:

Atlantic Development Group for Latin America

CCHEN: International Maize and Wheat Improvement Center

CORFO: Comisión Chilena de Energía Nuclear (National Commission for Nuclear Energy)

FAO: Corporación de Fomento de la Producción (Industrial Development Corporation)

FIA: UN Food and Agriculture Organization

FONDECYT: $\quad$ Fondo Nacional de Desarrollo Científico y Tecnológico (National Fund for Scientific and Technological Development)

FONDEF: $\quad$ Fondo para la Promoción del Desarrollo Científico y Tecnológico (Fund for the Promotion of Scientific and Technological Development)

GHG: $\quad$ Greenhouse Gas

IRRI: $\quad$ International Rice Research Institute

INDAP: $\quad$ Instituto de Desarrollo Agropecuario (Institute for Agriculture and Livestock Development)

INIA: $\quad$ Instituto Nacional de Investigacion Agropecuaria (National Institute for Agriculture and Livestock Research)

LAAD: $\quad$ Latin American Agribusiness Development Corporation

$\mathrm{N}$ : Nitrogen

NUE: $\quad$ Nitrogen Use Efficiency

ODEPA: $\quad$ Oficina de Estudios y Políticas Agrarias (Office of Agricultural Studies and Policy)

USAID: $\quad$ US Agency for International Development

\section{References}

Aber, J. 1995. Forest biogeochemistry and primary production altered by Nitrogen saturation. Water Air and Soil Pollution 85(3): 1665-1670.

Adams, M. 2004. Soil functional responses to excess Nitrogen inputs at global scale. Ambio 33(8): 530-536.

Arbuckle, J., L. Wright and J. Hobbs. 2013. Farmer beliefs and concerns about climate change and attitudes toward adaptation and mitigation: evidence from Iowa. Climatic Change 118(3): 551-563.

\footnotetext{
${ }^{13}$ Implementing programs to effectively reduce the use of agrochemicals among farmers, such as the Watershed Nutrient Task Force (1997) and the Nutrient Reduction Strategy (2008) in Iowa, United States, have bridged the gap between scientific knowledge and policy-making processes. They have also integrated the analytical tools and theoretical frameworks from social sciences that are fundamental to understanding, and effectively connecting, policy and behavior change on a local scale (Arbuckle 2013; Arbuckle and Bates 2015).
} 
Arbuckle, J., and H. Bates. 2015. Iowa farm and rural life poll - farmer perspectives on Iowa's nutrient reduction strategy. Iowa State University. http://drakeaglaw.org/wpcontent/uploads/2015/12/Arbuckle-and-Bates-2015-Farmer-Perspectives-on-Iowas-NutrientReduction-Strategy-PM3072.pdf

Balasubramanian, V., B. Alves, M. Aulakh, M. Bekunda, Z. Cai, L. Drinkwater, D. Mugendi, C. Van Kessel and O. Oenema. 2004. Crop, environmental, and management factors affecting nitrogen use efficiency. In A. Mosier and J. Freney (eds.) Agriculture and the Nitrogen cycle: assessing the impacts of fertilizer use on food production and environment. Washington D.C.: Island Press.

Barandiaran, J. 2015. Chile's environmental assessments: contested knowledge in an emerging democracy. Science as Culture 24(3): 251-271.

Bauer, C., and L. Catalán. 2016. Water, law, and development in Chile/California cooperation, 1960-70s. World Development 90: 184-198.

Billen, G., Garnier, J., and L. Lassaletta. 2013. The nitrogen cascade from agricultural soils to the sea: modeling nitrogen transfer at regional watershed and global scales. Philosophical Transactions of the Royal Society B 368: 20130123.

Blumental J.M., D.D. Baltensperger, K.G. Cassman, S. Mason and A.D. Pavlista. 2001. Importance and effect of nitrogen on crop quality and health. In R.F. Follett and J.L. Hatfield (eds.) Nitrogen in the environment: sources, problems, and management. Amsterdam: Elsevier Science.

Bown, S. 2005. A most damnable invention: dynamite, nitrates and the making of the modern world. New York: Thomas Dunne Books.

Boyer, E. and W. Horwarth. 2002. The nitrogen cycle at regional to global scales. Amsterdam: Springer.

Brenton, P., G. Edwards-Jones and M. Jensen. 2016. Carbon footprints and food systems: do current accounting methodologies disadvantage developing countries? Washington D.C.: World Bank.

Brown, L. 1999. Feeding nine billion. In L.R. Brown, C. Flavin and H. French (eds.) State of the World, 1999: a Worldwatch Institute report on progress toward a sustainable society. New York: Norton.

Carruthers, D. 2001. Environmental politics in Chile: legacies of dictatorship and democracy. Third World Quarterly 22 (3): 343-358.

Coppess, J. 2015. IFES 2015: Dead zones and drinking water: farming's nutrient loss challenge. Farmdoc daily. Department of Agricultural and Consumer Economics, University of Illinois at UrbanaChampaign. [accessed August 29 2016] http://farmdocdaily.illinois.edu/2015/12/ifes-2015-deadzones-drinking-water.html

Crews, T.E. and M.B. Peoples. 2004. Legume versus fertilizer sources of nitrogen: ecological tradeoffs and human needs. Agriculture, Ecosystems and Environment 102: 279-297

Cullather, N. 2004. Miracles of modernization: the Green Revolution and the apotheosis of technology. Diplomatic History 28 (2): 227-254.

Cullather, N. 2007. The foreign policy of the calorie. The American Historical Review 112(2): 337-364.

Cullather, N. 2010. The hungry world: America's Cold War battle against poverty in Asia. Cambridge: Harvard University Press.

Cushman, G. 2013. Guano and the opening of the Pacific world: a global ecological history. New York: Cambridge University Press.

Donohue, K. 2003. Freedom from want: American liberalism and the idea of the consumer. Baltimore: John Hopkins University Press.

EPA. 2011. Reactive Nitrogen in the United States. [accessed August 29 2016] http://www.unep.org/pdf/dtie/Reactive_Nitrogen.pdf

Ekbladh, D. 2011. The great American mission: modernization and the construction of an American world order. Princeton: Princeton University Press. 
Erisman, J., J. Galloway, S. Seitzinger, A. Bleeker, N. Dise, A. Trescu, A. Leach and W. de Vries. 2013. Consequences of human modification of the global nitrogen cycle. Philosophical Transactions of The Royal Society B Biological Sciences 368(1621): 20130116

Erisman, J., J. Galloway, N. Dise, M. Sutton, A. Bleeker, B. Grizzetti, A. Leach and W. de Vries. 2015. Nitrogen: too much of a vital resource. Science Brief. Zeist: WWF Netherlands.

Evans, C.D., J.M. Cullen, C. Alewell, J. Kopácek, A. Marchetto, F. Moldan, A. Prechtel, M. Rogora, M. Veselý and R. Wright. 2001. Recovery from acidification in European surface waters. Hydrology and Earth System Sciences 5(3): 283-297.

FAO. 1953. Report of the meeting on fertilizer production, distribution and utilization in Latin America. Rio de Janeiro, Brazil, 1951. FAO Development Papers 36. Rome: FAO.

FAO. 1957. Report of the meeting on soil fertility and fertilizers for the Latin American Region. Turrialba, Costa Rica. Turrialba: Inter-American Institute of Agricultural Sciences.

FAO - ECLA. 1950. Agricultural requisites in Latin America. Report of the Joint FAO/ECLA Working Party. New York: United Nations.

FAO - UNESCO. 1971. Soil map of the world. Volume IV South America. Paris: UNESCO.

Forman, D. 1988. Nitrate exposure and the carcinogenic process. Annals of the New York Academy of Sciences 534(1): 597-603

Galloway, J.N. 2001. Optimizing nitrogen management in food and energy production and environmental protection: contributed papers from the 2nd International Nitrogen Conference. Lisse: A.A. Balkema.

Galloway, J.N. and E.B. Cowling. 2002. Reactive nitrogen and the world: 200 years of change. Ambio 31(2): 64-71. Researchgate

Galloway, J.N., F.J. Dentener, D.G. Capone, E.W. Boyer, R.W. Howarth, S.P. Seitzinger and C.J. Vosmarty. 2004. Nitrogen cycles: past, present, and future. Biogeochemistry 70(2): 153-226.

Galloway, J.N., W. Schlesinger, H. Levy, A. Michaels and J.L. Schnoor. 1995. Nitrogen fixation: anthropogenic enhancement-environmental response. Global Biogeochemical Cycles 9(2): 235-252.

Gerhart, A. 2017. Petri dishes of an archipelago: the ecological rubble of the Chilean salmon farming industry. Journal of Political Ecology 24: 726-742.

Gordillo, G. 2014. Rubble: the afterlife of destruction. Durham N.C.: Duke University Press. Academia, intro

Gorman, H. 2013. The story of N: a social history of the nitrogen cycle and the challenge of sustainability. New Brunswick: Rutgers University Press.

Gupta, A. 1998. Postcolonial developments: agriculture and the making of modern India. Durham: Duke University Press.

Gwynne, R. 1998. Globalization, commodity chains and fruit exporting regions in Chile. Tijdschrift voor Economische en Sociale Geografie 90: 211-225.

Gwynne, R. and C. Kay. 1997. Agrarian change and the democratic transition in Chile: an introduction. Bulletin of Latin American Research 16(1): 3-10.

Hatfield J.L and J.H. Prueger. 2004. Nitrogen over-use, under-use, and efficiency. In T. Fischer et al. (eds.) New directions for a diverse planet. Proceedings of the 4th International Crop Science Congress. 2004, Brisbane, Australia. Gosford: The Regional Institute.

Hoelle J. 2017. Jungle beef: consumption, production and destruction and the development process in the Brazilian Amazon. Journal of Political Ecology 24: 743-762.

Holland, E.A., F.J. Dentener, B.H. Braswell and J.M. Sulzman. 1999. Contemporary and pre- industrial global reactive nitrogen budgets. Biogeochemistry 46(1-3): 7-43.

Horwarth, R.W., G. Billen, D. Swaney, A. Townsend, N. Jaworski, K. Lajtha and Z. Zhao-Liang. 1996. Regional nitrogen budgets and riverine $\mathrm{N}$ and $\mathrm{P}$ fluxes for the drainages to the North Atlantic Ocean: natural and human influences. Biogeochemistry 35(1): 75-139.

Horwarth, R.W., E.W. Boyer, W.J. Pabich and J.N. Galloway. 2002. Nitrogen use in the United States from 1961-2000 and potential future trends. Ambio 31(2): 88-96. 
Howard P. 2016. Concentration and power in the food system: who controls what we eat? London: Bloomsbury.

IPCC. 2007. Fourth assessment report of the Intergovernmental Panel on Climate Change. synthesis report. summary for policymakers. Geneva: Intergovernmental Panel on Climate Change.

IPCC. 2014. Mitigation of climate change. Working Group III contribution to the fifth assessment report of the Intergovernmental Panel on Climate Change. New York: Cambridge University Press.

Jarvis, L. 1985. Chilean agriculture under military rule: from reform to reaction, 1973-1980. Research Series 59. Berkeley: Institute of International Studies, University of California, Berkeley.

Jarvis, L. 1989. The unrevealing of Chile's agrarian reform, 1973-1986. In W. Thiesenhusen (ed.) Searching for agrarian reform in Latin America. Boston: Unwin Hyman.

Jarvis, L. 1994. Changing private and public roles in technological development: lessons from the Chilean fruit sector. In J. Anderson (ed.). Agricultural technology: current policy issues for the international community. Wallingford: CAB International.

Jenkinson, D. 2001. The impact of humans on the nitrogen cycle, with focus on temperate arable agriculture. Plant and Soil 228(1): 3 -15.

Kay, C. 2002. Chile's neoliberal agrarian transformation and the peasantry. Journal of Agrarian Change 2: 464-501.

Kennedy, I. R. 1986. Acid soil and acid rain: the impact on the environment of nitrogen and sulphur cycling. New York: Wiley.

Kinkela, D. 2013. DDT and the American Century: global health, environmental politics, and the pesticide that changed the world. Chapel Hill: The University of North Carolina Press.

Kloppenburg, J. 2005. First the seed: the political economy of plant biotechnology 1492-2000. Madison: University of Wisconsin Press.

Leigh, G. 2004. The world's greatest fix: a history of nitrogen and agriculture. Oxford: Oxford University Press.

Ling, E., D. Chen and R. Edis. 2016. Nitrogen pollution: the forgotten element of climate change. The Conversation. December 4 2016. [accessed December 15 2016] https://theconversation.com/nitrogenpollution-the-forgotten-element-of-climate-change-69348

Matson, P.A. 2012. Seeds of sustainability: lessons from the birthplace of the Green Revolution in agriculture. Washington, DC: Island Press.

Matson, P.A., K. Lohse and S.J. Hall. 2002. The globalization of nitrogen deposition: consequences for terrestrial ecosystems. Ambio 31(2): 113-119.

McNeill, J. and C. Unger (eds.) 2010. Environmental histories of the Cold War. Cambridge: Cambridge University Press.

Melillo, J.M., and E.B. Cowling. 2002. Reactive nitrogen and public policies for environmental protection. Ambio 31(2): 150-158.

Melillo, E. 2012. The first Green Revolution: debt peonage and the making of the nitrogen fertilizer trade, 1840-1930. The American Historical Review 117 (4): 1028-1060

Mellillo, E. 2015. Strangers on familiar soil: rediscovering the Chile-California connection. New Haven: Yale University Press.

Mosier, A. 1994. Nitrous oxide emissions from agricultural soils. Fertilizer Research 37: 191-200.

Mosier, A. 2001. Exchange of gaseous nitrogen compounds between agricultural systems and the atmosphere. Plant and Soil 228: 17-27.

Mosier, A., J.K. Syers and J.R. Freney (eds.). 2004. Agriculture and the nitrogen cycle: assessing the impacts of fertilizer use on food production and environment. Washington D.C.: Island Press.

Motta, R., R. Huber and J. Ruitenbeek. 1999. Market Based Instruments for environmental policymaking in Latin America and the Caribbean: lessons from eleven countries. Environment and Development Economics 4(02): 177-201. 
Muir, C. 2014. The broken promise of agricultural progress: an environmental history. New York: Routledge.

Office of War Information. 1942. The United Nations fight for the four freedoms. January 1, 1942. Washington D.C.: Government Printing Office.

Olsson, T. 2012. Green Revolutions: Rockefeller agronomy from the American South to Mexico. [accessed August 29 2016] http://www.rockarch.org/publications/resrep/olsson.pdf.

Olsson, T. 2016. U.S. regionalism and the many histories of the Green Revolution. HistPhil. 7 January.

Otero, G. 2013. Food for the few: neoliberal globalism and biotechnology in Latin America. Austin: University of Texas Press.

Partridge, T. 2017. Resisting ruination: resource sovereignties and socioecological struggles in Cotopaxi, Ecuador. Journal of Political Ecology 24: 763-776.

Pearse, A. 1980. Seeds of plenty, seeds of want: social and economic implications of the Green Revolution. United Nations Research Institute for Social Development. Oxford: Oxford University Press.

Peoples, M., E. Boyer, K. Goulding, P. Heffer, V. Ochwoh, V. Vanlauwe, S. Wood, K. Yagi and O. Vleemput. 2004. Pathways of nitrogen loss and their impacts on human health and the environment. In A. Mosier and J. Freney (eds.) Agriculture and the Nitrogen cycle: assessing the impacts of fertilizer use on food production and environment. Washington D.C.: Island Press.

Perkins, J. 1997. Geopolitics and the Green Revolution: wheat, genes and the Cold War. Oxford: Oxford University Press.

Potter, P., N. Ramankutty, E. Bennett and S. Donner. 2010. Characterizing the spatial patterns of global fertilizer application and manure production. Earth Interactions 14(2): 1-22. Researchgate

Raggi, R. 1969. Estudio de la lixiviacion del $\mathrm{N}-\mathrm{NO}_{3}$ en un suelo arrayan de la provincia de Nuble. Tesis presentada a la Escuela de Agronomia de la Universidad de Concepcion para optar al titulo de Ingeniero Agronomo. Chillán: Universidad de Concepción.

Rohter, Larry. 2007. Scientists are making Brazil's savannah bloom. New York Times. [accessed August 9 2016] http://www.nytimes.com/2007/10/02/science/02tropic.html?pagewanted=all\&_r $=0$

Ross, R. 2000. Mission possible: the Latin American Agribusiness Development Corporation. New Brunswick: Transaction Publishers.

Rockefeller Foundation. 1951. The world food problem, agriculture, and the Rockefeller Foundation. [accessed August 29 2016]

Schmalzer, S. 2016. Red Revolution, Green Revolution: scientific farming in socialist China. Chicago: University of Chicago Press.

Shiva, V. 1991. The violence of the Green Revolution: Third world agriculture, ecology and politics. Atlantic Highlands: Zed Books.

Silva, E. 1996. The state and capital in Chile: business elites, technocrats and business economics. Boulder: Westview.

Smil, V. 1999. Nitrogen in crop production: an account of global flows. Global Biogeochemical Cycles 13(2): 647-662.

Smil, V. 2001. Enriching the earth: Fritz Haber, Carl Bosch and the transformation of world food production. Cambridge: MIT Press.

Smil, V. 2004. Improving efficiency and reducing waste in our food system. Environmental Sciences 1:17-26.

Smith, J. 2014. Works in progress: plans and realities on Soviet Farms 1930-1963. New Haven: Yale University Press.

Stads, G. and N. Beintema. 2009. Public agriculture research in Latin America and the Caribbean: investment and capacity trends. Washington, D.C.: International Food Policy Research Institute (IFPRI), Inter-American Development Bank.

Staples, A. 2006. The birth of development: how the World Bank, Food and Agriculture Organization, and World Health Organization changed the world, 1945-1965. Kent: Kent State University Press. 
Sutton, M. (ed.) 2011. The European Nitrogen Assessment. New York: Cambridge University Press.

Tecklin, D., C. Bauer and M. Prieto. 2011. Making environmental law for the market: the emergence, character, and implications of Chile's environmental regime. Environmental Politics 20(6):879-898.

Tinsman, H. 2014. Buying into the regime: grapes and consumption in Cold War Chile and the United States. Durham: Duke University Press.

Tomich, T., S. Brodt, R. Dahlgren and K. Scow (eds.). 2016. The California Nitrogen Assessment. Oakland: University of California Press.

Tubiello, F. N., Salvatore, M., Rossi, S., Ferrara, A., Fitton, N., and P. Smith. 2013. The FAOSTAT database of greenhouse gas emissions from agriculture. Environmental Research Letters 8(1).

Valdés, A. 1976. Protección a la industria de fertilizantes y su efecto sobre la producción agrícola y el ahorro de divisas: el caso del Salitre. Cuadernos de Economía 39: 93-108.

Van Drecht, G., A.F. Bouwman, J.M. Knoop, A.H.W. Beusen and C.R. Meinardi. 2003. Global modeling of the fate of nitrogen from point and nonpoint sources in soils, groundwater, and surface water. Global Biogeochemical Cycles 17(4): 632-41. Researchgate

Venezian, E. 1987. Chile and the CGIAR centers: a study of their collaboration in agricultural research. Washington, DC: The World Bank.

Venezian, E. 1993. A case of university participation in national agricultural research: the faculty of agriculture, Catholic University of Chile. FAO Research and Technological Papers 5. Rome: FAO.

Venezian, E. and E. Muchnik. 1995. Chile. In S. Tabor (ed.) Agricultural research in an era of adjustmen: policies, institutions, and progress. Washington, D.C.: The World Bank.

Vitousek, P.M., J.D. Aber, R.W. Howarth, G.E. Likens, P.A. Matson, D.W. Schindler and D.G. Tilman. 1997. Human alteration of the global nitrogen cycle: sources and consequences. Ecological Applications 7(3): 737-750.

Vitousek, P.M., S. Hättenschwiler, L. Olander and S. Allison. 2002. Nitrogen and nature. Ambio 31(2): 97101.

West, P.C., J.S. Gerber, N.D. Mueller, K.A. Brauman, K.M. Carlson, E.S. Cassidy, P.M. Engstrom, M. Johnston, G.K. MacDonald, D.K. Ray and S. Siebert. 2014. Leverage points for improving food security and the environment. Science 345:325-328.

Worster, D. 1990. Transformations of the earth: toward an agroecological perspective in history. The Journal of American History 76(4): 1087-1106. 